\title{
USAHA PERKEDEL TEMPE GORENG (PerTego)
}

\author{
Maria Tia, Fransiska Lempan Tiboyong
}

\begin{abstract}
Abstrak
Perkedel tempe goreng adalah olahan daging ayam ditambah dengan tempe yang dibuat dengan Teknik pembuatan bakso. Selanjutnya dibentuk menjadi bentuk bulat seperti perkedel kentang lalu digoreng. Nilai gizinya yang ditonjokan adalah dalam tempenya. Uji organoleptic menunjukkan nilai suka secara keseluruhan. Evaluasi terhadap produk ini menghasilkan produk olahan yang menggunakan daging ayam yang sebelumnya tidak menggunakan daging olahan menunjukkan nilai organoleptik yang rendah. Nilai jual produk ini terjangkau dan bisa dijadikan lauk pauk.
\end{abstract}

Kata-kata kunci: perkedel, tempe, gizi, usaha, evaluasi, uji organoleptik

\section{PENDAHULUAN}

Tempe merupakan salah satu bahan makanan yang murah meriah dan mudah di dapat dan merupakan bahan makanan asli Indonesia. Di seluruh penjuruh Indonesia, kita dapat menemukan tempe tanpa kesulitan. Tempe adalah makanan yang terbuat dari fermentasi terhadap biji kedelai atau beberapa bahan lain yang memnggunakan beberapa jenis kapang Rhizopus, Rh. Oryzae, Rh. Stolonifer (kapang roti), atau Rh.arrhizus. sediaan fermentasi ini secara umum dikenal sebagai "ragi tempe". Tempe di pasarkan dimana saja baik di pasar tradisional, pasar moderen, di supermarket bahkan penjual sayur kelilingpun juga dengan setia mereka membawa tempe. Tempe adalah salah satu makanan gaya hidup orang Indonesia dan mempunyai banyak manfaat bagi tubuh. Karena tempe banyak mengandung protein yang tinggi dibandingkan dengan daging. 
Yang kita ketahui selama ini adalah bahwa perkedel adalah makanan yang terbuat dari kantang atau jagung yang sudah di haluskan, di campur daging, irisan daun bawang dan bumbu-bumbu lainnya. Namun, kali ini perkedelnya dari bahan tempe, yang dicampur dengan daging serta bumbu-bumbu lainnya. Maka dari itu, penulis ingin menawarkan produk ini kepada masyarakat untuk bekerja sama. Dari pruduk ini penulis memberi nama "Perkedel Tempe Goreng".

\section{BAHAN DAN GAMBARAN YANG DIGUNAKAN DALAM PRODUK}

Dalam produk ini kami beri nama "Perkedel Tempe Goreng". Mengapa?

Karena ini merupakan suatu produk yang unik dan menarik. Yang kebanyakan orang tahu dan kenal adalah perkedel jagung atau perkedel kentang.

\section{Komposisi Bahan Dasar}

Tempe 2 lapis ukuran 15 x $15 \mathrm{~cm}$

Wortel 2 batang

Tepung Tapioka secukupnya

Tepung biasa secukupnya

Telur 5 butir

Ayam 1ekor

Daun bawang

Bawang merah

Bawang putih

Lombok besar merah

Garam

Merica

Royco

Minyak goreng

Tusuk bakso

Jeruk nipis

\section{Tempe}

Tempe merupakan bahan dasarnya dari kacang kedelai yang di fermentasi. Tempe merupakan makanan tradisional Indonesia yang sudah dikenal berabad-abad yang lalu, terutama dalam budaya makanan khas masyarakat Jawa khususnya 
Yogyakarta dan Surakarta. ${ }^{1}$ Tempe memiliki kandungan gizi dan zat fitokimia (zat nongizi) yang berkualitas. Tempe tidak hanya memiliki kandungan gizi makro, tetapi juga kaya akan zat gizi mikro seperti vitamin B kompleks dan mineral zink serta zat besi $^{2}$. Jenis Vitamin yang terkandung dalam tempe antara lain vitamin B (tiamin), B2 (riboflamin), B3 (niasin), B6 (pirioksin), B12 (sianokobalamin) dan asam pantotenat. ${ }^{3}$ Tempe memiliki manfaat untuk kesehatan diantaranya sebagai tempe memiliki sumber protein yang lebih tinggi daripada daging dan mudah dicerna sehingga baik untuk megatasi diare; mengandung zat besi, flafoid yang bersifat antioksidan sehingga menurunkan tekanan darah; mengandung superoksida desmutase yang dapat mengendalikan radikal bebas, baik untuk penderita jantung; penanggulangan anemia. Anemia ditandai dengan rendahnya kadar hemoglobin karena kurang tersedianya zat besi $(\mathrm{Fe})$, tembaga $(\mathrm{Cu})$, seng $(\mathrm{Zn})$, protein, asam folat dan vitamin $\mathrm{B} 12$, di mana unsurunsur tersebut terkandung dalam tempe; anti infeksi; daya hipokolestrol. ${ }^{4}$ Kandungan asam lemak jenuh ganda pada tempe bersifat dapat menurunkan kadar kolestrol; memiliki anti oksidan, menolak kanker; mencegah timbulnya hipertensi; kandungan kalsiumnya yang tinggi, tempe dapat mencegah osteoporosis. ${ }^{5}$ Walaupun tempe memiliki banyak manfaat bagi kesehatan, tempe juga tidak baik jika di konsumsi secara berlebihan. Tempe tidak baik untuk di konsumsi oleh penderita asam urat. Penderita asam urat biasanya disarankan untuk mengindari makanan dengan makanan kandung zat purin tinggi. Tempe mengandung Zat purin yang rendah sehingga masih bisa untuk

\footnotetext{
${ }^{1}$ Susianto, Rita Ramayulis, Fakta Ajaib Khasiat Tempe (Jakarta: Penebar Plus, 2013), 7

${ }^{2}$ Susianto, Rita Ramayulis, 5

${ }^{3}$ Ibid.

${ }^{4}$ Yulianto (ed.), "Mengapa Tempe Penuh Khasiat?"

https://tabloidsinartani.com/detail/indeks/family-style/8393-Mengapa-Tempe-Penuh-Khasiat ${ }^{5}$ Ibid.
} 
di konsumsi tetapi tidak disarankan untuk di konsumsi secara terus menerus/setiap hari ${ }^{6}$.

Tempe sangat baik untuk kesehatan tetapi tidak untuk di konsumsi setiap harinya.

Tabel 1. Kandungan Gizi Tempe

\begin{tabular}{lll}
\hline NO & JENIS & JUMLAH \\
\hline $\mathbf{1}$ & Protein (g) & 20,7 \\
$\mathbf{2}$ & Lemak (g) & 8,8 \\
$\mathbf{3}$ & karbohidrat (g) & 13,5 \\
$\mathbf{4}$ & Serat (g) & 3,2 \\
$\mathbf{5}$ & Kalsium (mg) & 155,1 \\
$\mathbf{6}$ & Fosfor (mg) & 323,6 \\
$\mathbf{7}$ & Besi (mg) & 4,0 \\
$\mathbf{8}$ & Vitamin B12 & 1,7 \\
\hline
\end{tabular}

Tabel 2. Hasil Uji Organoleptik sebagai Evaluasi sebelum pengembangan ${ }^{7}$

\section{PENILAIAN \\ HASIL \\ PENILAIAN}

1. AROMA $\quad 3,625$

${ }^{6}$ Ibid.

${ }^{7}$ Uji organoleptik mengikuti metode yang dikutip olehHengki Wijaya and Tuflikha P. Putri, “KEWIRAUSAHAAN NAMEKO (NASI MERAH KOTAK-KOTAK) DALAM MENGGIATKAN PANGAN LOKAL YANG SEHAT" (Prosiding Seminar Nasional Pangan, Teknologi, dan Entrepreneurship, Makassar, Indonesia: Universitas Fajar Makassar, 2019), https://osf.io/vzd48. 


\begin{tabular}{|l|l|}
\hline 2. TEKSTUR & 2,75 \\
\hline 3. RASA & 2,5 \\
\hline 4. WARNA & 4 \\
\hline 5. ALL & 3,375 \\
\hline
\end{tabular}

Hasil tersebut di atas adalah evaluasi terhadap produk sebelumnya yang dinilai. Penulis ingin membuat bakso tempe dengan campuran wortel. Setelah produk melalui uji organoleptic memiliki nilai produk adalah 3,375. Nilai tersebut menunjukkan bahwa produk masih bisa dikembangkan kearah yang lebih baik. Oleh karena itu, produk ini dikembangkan kea rah produk perkedel dengan tambahan daging ayam dan tetap mempertahankan tambahan tempe, dan wortel. Penulis memilih bumbu yang tepat untuk pembuatan perkedel. Hasil produk yang dijual lebih baik dan ebih kenyal seperti bakso goreng walaupun Namanya perkedel tempe goreng.

Tabel 3. Hasil Jualan Perkedel Tempe Goreng

\begin{tabular}{|l|l|l|l|}
\hline NO & PRODUK & DISIAPKAN & TERJUAL \\
\hline 1 & Perkedel Tempe Goreng & 120 tusuk & 120 tusuk \\
\hline
\end{tabular}

\section{ANALISA SWOT ${ }^{8}$}

\section{Strengths/kekuatannya}

Dari pruduk perkedel ini adapun yang kekuatan yang bisa kami miliki sebagai berikut:

\footnotetext{
${ }^{8}$ Penulis mengikuti kaidah analisis SWOT berdasarkan tulisan Hengki Wijaya, "Analisis SWOT Tentang Pembinaan Kesiswaan dan Pengembangan Program Pembinaan Siswa," 2018, https://www.researchgate.net/profile/Hengki_Wijaya3/publication/325493778_Analisis_SWOT_Tentang _Pembinaan_Kesiswaan_dan_Pengembangan_Program_Pembinaan_Siswa/links/5b113deaaca2723d9979 79ac/Analisis-SWOT-Tentang-Pembinaan-Kesiswaan-dan-Pengembangan-Program-PembinaanSiswa.pdf.
} 
$\checkmark$ Harganya terjangkau. Karena perkedel tempe ini dapat di beli oleh anak-anak sekolahan maupun orang-orang dewasa. Kami menjualnya dengan harga Rp 2.000/tusuk.

$\checkmark$ Bahannya praktis. Bahan-bahan yang digunakan sangat mudah di dapatkan dan sangat dapat dijangkau.

$\checkmark$ Tampilannya menarik dan unik. Kebanyakan orang kenal adalah perkedel jagung dan atau perkedel kentang. Namun kali ini adalah perkedel tempe yang dibentuk yang unik dan di tusuk pada tusuk sate.

$\checkmark$ Dapat digunakan sebagai cemilan. Perkedel tempe goreng dapat di konsumsi seperti cemilan dan atau sebagai lauk

\section{Weakness/kelemahan}

$\checkmark$ Mudah di tiru. Proses pembuatan perkedel tempe goreng ini sangatlah mudah sehingga mudah di ikuti/ditiru oleh siapapun.

$\checkmark$ Pengeluaran modal bisa dikatakan besar

\section{Opportunities/peluang}

$\checkmark$ Sangat menguntungkan dari produk ini karena di daerah pemasaran belum terlalu banyak yang menjual.

$\checkmark$ Harganya terjangkau

\section{Threats/ancaman}

Semua orang dapat membuat/mempraktek produk ini (perkedel tempe goreng) karena perkedel tempe ini sangat mudah untuk di olah 


\section{PELAKSANAAN}

\section{Cara Pembuatan}

Dalam membuat perkedel tempe ini tidak berbeda jauh dengan pembuatan perkedel-perkedel lainnya. Berikut adalah cara pembuatan Perkedel Tempe sebagai berikut:

1. Ayam di cuci bersih lalu di vilet (pisahkan daging dari tulang-tulangnya). Di iris kecil-kecil lalu di kasih garam, merica, air jeruk dan gula pasir sedikit. Setelah itu direbus dengan air secukupnya dan dengan api yang sedang. Ayam direbus \pm 15 menit lalu di belender kasar.

2. Menyediakan kukusan untuk mengukus tempe.

3. Sambil menunggu airnya mendidih, tempenya dicuci lalu di potong-potong kecil. Setelah airnya mendidih kita mengukus tempe yang telah dipotong-potong tersebut. Tempenya di kukus sampai setengah matang atau kurang lebih 5 menit. Setelah itu di tumbuk-tumbuk halus.

4. Wortel 2 batang di kupas kulitnya, dicuci bersih lalu di parut halus.

5. Daun bawang di cuci bersih lalu di iris-iris tipis kecil

6. Lombok besar merah di keluarkan bijinya lalu dicuci bersih, di potong-potong kecil lalu di cincang-cincang halus.

7. Bawang putih 8 siung dan bawang merah 3 siung di cincang-cincang halus

8. Ayam yang telah di belender tersebut di campur dengan tempe yang telah ditumbuk halus tersebut.

9. Setelah itu masukan garam, merica, penyedap, gula, telur 3 butir tepung tapoika dan tepung biasa secukupnya. Diaduk sampai rata.

10. Selanjutnya masukan parutan wortel, daun bawang dan lombok merah besar kedalam adonan. Diaduk sampai semua bahannya benar-benar tercampur. 
11. Adonannya siap dibentuk bulat sesuai dengan keinginan. Sambil kita membentuk adonan, kita masak air secukupnya untuk rebus perkedel tempe yang sudah dibentuk.

12. Setelah airnya mendidih, masukan perkedelnya. Masak sampai mengapung lalu di angkat dan di tiriskan.

13. Sediakan wajan dan minyak goreng untuk menggoreng.

14. Perkedel yang sudah di rebus, disimpan di satu wadah yang lebar dan kocok telur ayam sekitar 2 atau 3 butir campur dengan perkedel yang sudah di rebus tersebut.

15. Goreng sampai kuning ke emasan.

16. Perkedel Tempe siap di sajikan

\section{Lokasi Penjualan}

Lokasi pemasaran dimana penulis akan membuka usaha tersebut adalah di sekitar daerah-daerah yang ramai seperti di emperan persekolahan, di sekitar tempattempat ibadah, dilapangan-lapangan umum seperti tempat orang berolaraga. Selain itu penulis juga akan menjual keliling atau memakai gerobak dorong.

\section{ANGGARAN DANA ${ }^{9}$}

Dengan mengelola perkedel tempe ini maka dana yang awal yang kami gunakan dan butuh dalam pengelolaan perkedel tempe adalah sebesar Rp 127.000. dengan rincian sebagai berikut:

- Tempe 2 lapis ukuran 15 x $15 \mathrm{~cm}$ $\operatorname{Rp} 10.000$

- Wortel 2 batang Rp 6.000

${ }^{9}$ Untuk contoh pembiayaan mengikuti aturan pembuatan proposal kewirausahaan yang ditulis Jonathan Matheus et al., "Proposal Kegiatan Kreativitas Handmade BOLU (Boneka Lucu)," 2019, https://osf.io/nwdap/. 
- Ayam 1 Ekor

Rp 50.000

- Telur ayam 6 butir

Rp 12.000

- Daun bawang

Rp 2.000

- Lombok besar merah

Rp 2.000

- Tepung Tapoika

$\operatorname{Rp} 8.000$

- Tepung biasa

Rp 9.000

- Jeruk Nipis

Rp 2.000

- Minyak goreng

Rp 13.000

- Bawang putih

Rp 5.000

- Bawang merah

Rp 5.000

- Garam

Rp 1.000

- Merica

Rp 1.000

- Royco

Rp 1.000

Total keseluruhan anggaran yang dibutuhkann adalah sebesar Rp 127.000. perkedel tempe goreng dijual dengan harga Rp 2.000/tusuk. Jumlah hasil jualan semuanya sebesar 120 tusuk $(\operatorname{Rp} 2.000)=\operatorname{Rp} 240.000$. dari hasil penjualan perkedel tempe goreng ini kami memperoleh keuntungan sebesar Rp 240.000- Rp 127.000=Rp 113.000 .

\section{PENUTUP}

Dengan melalui matakuliah Entrepreneuship ini bersyukur dapat pembelajaran yang luar biasa, karena bisa belajar dan mengenal kewirausahaan. Dengan membuat suatu usaha atau satu produk membuat kami untuk berani ambil resiko walaupun produk yang kami buat yakni "perkedel tempe goreng" ini kelihatannya sepela atau 
gampang/mudah untuk di olah tetapi setelah kita praktek secara langsung tidaklah mudah bagi kami.

Dari sini kami belajar dalam membuka suatu usaha kita harus belajar untuk berani ambil resiko, belajar untuk tekun dan berani untuk mencoba walaupun itu kelihatannya aneh dan tidak mungkin untuk di coba. Tetap terima masukan-masukan yang di berikan oleh orang lain walaupun itu membuat kita tidak semangat lagi tetapi itulah yang harus kita pelajari.

Terimakasih biarlah dengan melalui matakuliah ini dan juga dengan pruduk "perkedel tempe goreng" ini dapat membantu pelayanan kami kedepan.

\section{DOKUMENTASI}
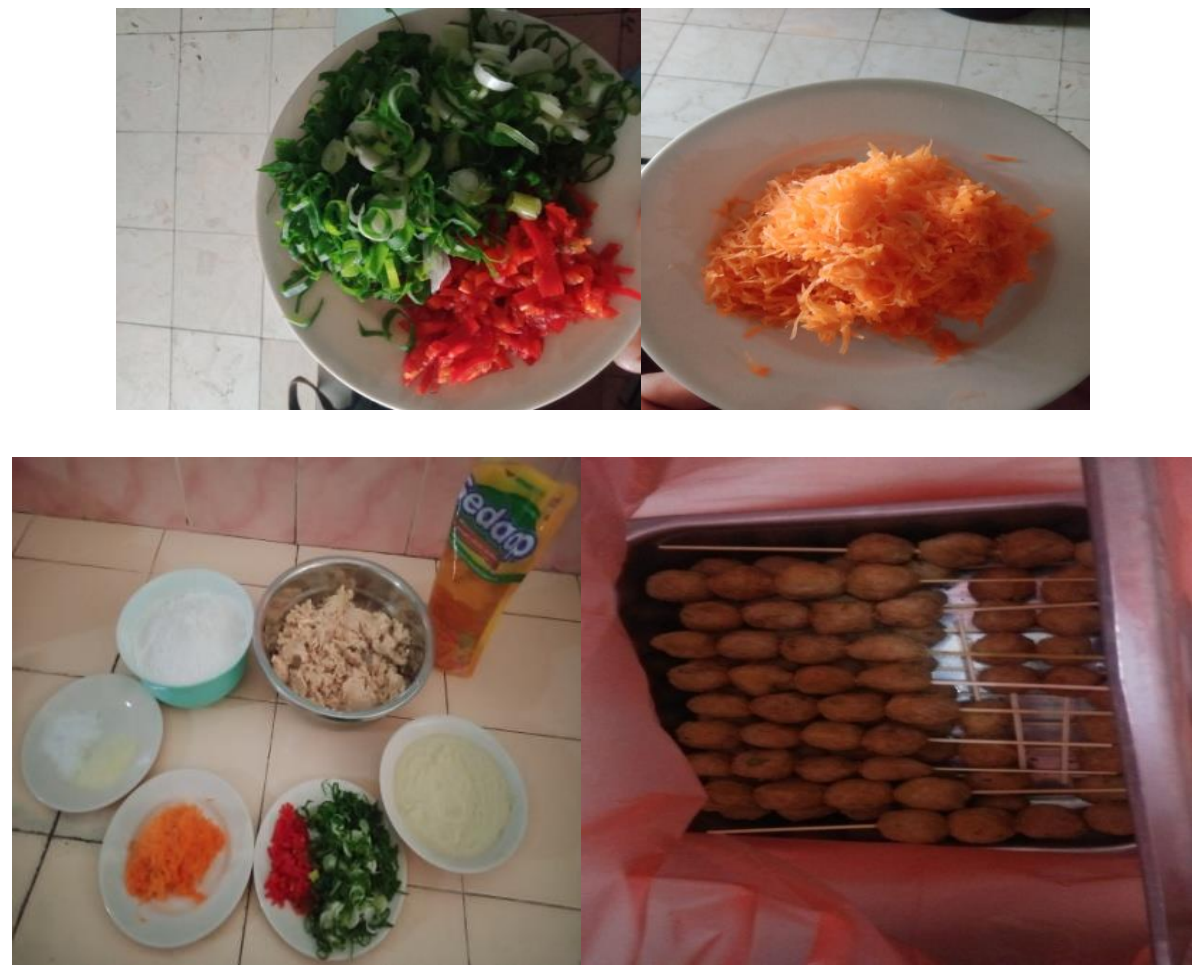


\section{Kepustakaan}

Matheus, Jonathan, Hengki Wijaya, Grace Irene Kalamu, and Josevina Maria Penfani. "Proposal Kegiatan Kreativitas Handmade BOLU (Boneka Lucu)," 2019. https://osf.io/nwdap/.

Susianto, Rita Ramayulis. Fakta Ajaib Khasiat Tempe.Jakarta: Penebar Plus, 2013.

Yulianto (ed.), "Mengapa Tempe Penuh Khasiat?"

https://tabloidsinartani.com/detail/indeks/family-style/8393-Mengapa-TempePenuh-Khasiat

Wijaya, Hengki. "Analisis SWOT Tentang Pembinaan Kesiswaan dan Pengembangan Program Pembinaan Siswa," 2018.

https://www.researchgate.net/profile/Hengki_Wijaya3/publication/325493778_

Analisis_SWOT_Tentang_Pembinaan_Kesiswaan_dan_Pengembangan_Progra m_Pembinaan_Siswa/links/5b113deaaca2723d997979ac/Analisis-SWOT-

Tentang-Pembinaan-Kesiswaan-dan-Pengembangan-Program-PembinaanSiswa.pdf.

Wijaya, Hengki, and Tuflikha P. Putri. "KEWIRAUSAHAAN NAMEKO (NASI MERAH KOTAK-KOTAK) DALAM MENGGIATKAN PANGAN LOKAL YANG SEHAT.” Makassar, Indonesia: Universitas Fajar Makassar, 2019. https://osf.io/vzd48. 